\title{
$11: 6581588-6588677$
}

National Cancer Institute

\section{Source}

National Cancer Institute. 11:6581588-6588677. NCI Thesaurus. Code C45000.

Physical location of ILK_Gene 